\title{
AÇÃO RESCISÓRIA E ENFRAQUECIMENTO DA COISA JULGADA: INFLUÊNCIAS DA SOCIEDADE DA INFORMAÇÃO E DA MODERNIDADE LÍQUIDA SOBRE O PROCESSO CIVIL ${ }^{1}$
}

\section{MOTION TO SET ASIDE JUDGEMENT AND RES JUDICATA'S WEAKENING: INFORMATION SOCIETY AND LIQUID MODERNITY INFLUENCES ON THE CIVIL PROCEDURE}

Beatriz Martins de Oliveira Mestre em Direito da Sociedade da Informação, especialista em Direito Processual Civil e bacharel em Direito, pelo Centro Universitário das Faculdades Metropolitanas Unidas. Advogada. São Paulo, SP. E-mail: beatriz.moliveira@outlook.com

Vinícius Garcia Ribeiro Sampaio Mestre e bacharel em Direito pelo Centro Universitário das Faculdades Metropolitanas Unidas. Pesquisador do grupo de pesquisa Ética e Democracia na Sociedade da Informação. Advogado. São Paulo, SP. E-mail: viniciussampaiodir@gmail.com.br

RESUMO: Este artigo analisa a ação rescisória na Sociedade da Informação, considerando a ampliação da visibilidade de decisões judiciais, sopesando a possibilidade de que a internet tenha o potencial de minar a estabilidade social garantida pela coisa julgada, especialmente diante da expectativa de coesão jurisprudencial. Embora eventual decisão de provimento em ação rescisória não tenha efeitos extra partes, ela inevitavelmente aparece indexada em sites de busca e pode servir como fundamento a novas demandas. Nesse sentido, a massificação de litígios passa a poder alcançar medidas processuais mais restritas e específicas. Para tanto, emprega-se a metodologia científica jurídico-sociológica.

\footnotetext{
${ }^{1}$ Artigo recebido em 02/07/2020 e aprovado em 18/03/2021.
} 
PALAVRAS-CHAVE: Ação Rescisória; Relativização da Coisa Julgada; Sociedade da Informação; Modernidade Líquida; Jurisprudência.

\begin{abstract}
This article analyzes the motion to set aside judgement in the Information Society, considering the increased visibility of judicial decisions, pondering the possibility that the internet have the potential to undermine the social stability guaranteed by res judicata, especially in a context in which case law cohesion is expected. Although an eventual decision in a motion to set aside judgement does not have effects beyond its litigants, it inevitably appears indexed in search engines and may serve as a basis for new demands. In this sense, the dispute massification becomes able to reach more restricted and specific procedural measures. For that, it is used the legal-sociological methodology.
\end{abstract}

KEYWORDS: Motion to set aside judgement; Res judicata relativization; Information Society; Liquid modernity; Case law.

\title{
INTRODUÇÃO
}

A Sociedade da Informação tem seus efeitos multiplicados pelas tecnologias que permitem o tratamento e a disseminação de informações a níveis nunca imaginados. $\mathrm{O}$ legislador de 1973 não poderia prever a realidade em que seus preceitos processuais seriam aplicados em 2014, assim como mesmo o legislador de 2015 desconhecia a realidade atual e a que está por vir. O Direito tem por característica sua constância, sua demora em inovar. É impossível que a lei acompanhe o avanço tecnológico sempre a contento, de forma que por vezes, no âmbito civil, há que se preferir artigos abertos, que possam ter sua aplicação prolongada no tempo. Por outro lado, essa perenidade parece ser um porto seguro em face da liquidez característica da pós-modernidade e do elevado fluxo de informação que, combinados, têm o potencial de banalizar a ação rescisória, enfraquecendo a coisa julgada.

A publicação e indexação de decisões judiciais na internet provocou uma transformação significativa na forma como os operadores do Direito lidam com o Judiciário, de modo que o conhecimento acerca delas se tornou amplo, praticamente 
irrestrito, a ponto de não mais se verificar somente a orientação jurisprudencial de determinado tribunal, mas sim decisões individuais, a exemplo de acórdãos isolados, em poucos segundos, a partir de uma rápida busca por palavras-chave, com filtros por área, tribunal etc. Essa superpublicidade das decisões judiciais vem provocando um efeito bastante perceptível no dia a dia forense: ementas de acórdãos já são utilizadas em diversas manifestações por litigantes como fundamento jurídico para seus pedidos.

O diploma processual de 2015 ampliou a necessidade de observância de precedentes e de uniformização da jurisprudência. Para além das especificidades técnicas dessa inovação, é bastante perceptível a hipertrofia da jurisprudência, que já vem deixando de ser vista como mera fonte secundária do direito ou simples resultado da aplicação da norma, em detrimento de uma visão que a considera como forma de expressão do Direito cuja importância é ressaltada pela construção hermenêutica da norma jurídica, ou seja, o direito a ser aplicado não consiste numa leitura acrítica ou simplesmente formalista dos textos legais; ao contrário, a norma jurídica é resultado justamente da interpretação que lhe dá o Judiciário.

A norma procedimental, assim como todo o ordenamento, não permanece hermeticamente isolada das transformações sociais em curso; ao contrário, sua aplicação diuturna sofre influência constante das mudanças tecnológicas e socioeconômicas. É interessante notar que a relação entre processo e tecnologia não consiste meramente na digitalização de autos processuais ou em plataformas on-line de solução de conflitos, mas, mais profundamente, à medida que o conhecimento provido pela Sociedade da Informação e a fluidez característica da Modernidade Líquida influenciam o Direito, os institutos jurídicos tradicionais começam a ser postos em xeque.

Nesse sentido, os efeitos da decisão judicial, ao contrário do que intenciona o legislador, não parecem mais se restringir exclusivamente aos litigantes, mesmo nas situações em que são tidos por inter partes. Isso porque a superpublicidade das decisões enseja efeitos indiretos a terceiros, calcados em dois fatores, quais sejam (i) o amplo e rápido conhecimento por todo e qualquer interessado (pela informação, mesmo sem interesse processual) e (ii) a hipertrofia da jurisprudência enquanto forma de expressão do Direito, fortalecida pelo legislador do CPC/2015, de tal forma que, apesar de eventuais restrições técnicas (a começar pela própria previsão de como a uniformização 
jurisprudencial ou a aplicação de precedentes deve ocorrer em casos concretos), passa a ser um importante fator de influência para as decisões judiciais.

A par disso, observa-se um processo de liquefação da coisa julgada, sólida até pouco tempo atrás, mas que agora começa a perder sua força em detrimento de iniciativas que intentam relativizá-la - (i) de fato, por meio de propostas de rescisão sem ação rescisória, ou (ii) a partir da mitigação de seus efeitos, pela possibilidade de maior recorrência desse tipo excepcional de ação, tido pela doutrina como remédio extremo, a partir do possível ajuizamento de ações em efeito manada, fenômeno recorrente no Judiciário que tende a se tornar mais frequente a partir da ampla disponibilidade de resultados de demandas a todo instante no País.

Diante desses fatores, as reflexões do presente artigo levam a crer que se deve ter atenção ao fenômeno que envolve a superpublicidade das decisões judiciais no contexto da Sociedade da Informação e da Modernidade Líquida, a fim de que as transformações pelas quais o Judiciário inevitavelmente continuará a passar em decorrência das mudanças sociais não sejam antagônicas à expectativa de segurança jurídica necessária ao Estado de Direito, que por sua vez depende, sem sombra de dúvidas, da solidez da coisa julgada.

A análise do artigo é realizada através da metodologia de pesquisa jurídicosociológica, que compreende o direito no quadro social, e se utiliza de pesquisa bibliográfica. Assim, o artigo divide-se em três capítulos, que são dedicados ao estudo, respectivamente, da jurisprudência na Sociedade da Informação, da ação rescisória e ao final, condensando os capítulos anteriores, da ação rescisória na Sociedade da Informação.

\section{A JURISPRUDÊNCIA NA SOCIEDADE DA INFORMAÇÃO}

O Código de Processo Civil de 2015 nasceu no apogeu da Sociedade da Informação até aqui. Pode-se dizer que o diploma anterior, de 1973, surgiu em sua fase inicial, quando a informática começava sua evolução para o que temos hoje. Como resultado, os microchips atuais, de tamanho mínimo, já têm maior capacidade de processamento e armazenamento de dados do que os computadores gigantes da década de 1970, que ocupavam escritórios inteiros. Não se pode confundir, entretanto, a Sociedade da Informação com a tecnologia que a sustenta: os computadores, a internet etc. são 
intrínsecos a essa nova organização social, mas não consistem nela própria, não são o fator mais relevante a se considerar. O que prepondera, nesse sentido, é a informação enquanto valor, recurso, processo e produto.

É nesse contexto que a rede mundial de computadores, ambiente que democratizou a comunicação a ponto de toda e qualquer pessoa poder ser emissora de informação, tornou-se um dos principais - se não o principal - meio em que a sociedade realiza suas pesquisas, normalmente a partir de sites de busca, como o Google, por exemplo. Esse fenômeno, por sua ampla abrangência, passou a influenciar inclusive as atividades forenses. O novo diploma processual trouxe a possibilidade de atos processuais à distância, como citação por meio digital, audiência por videoconferência, para além da digitalização de autos processuais, sempre almejando maior celeridade e adequação aos novos tempos.

A atividade jurisprudencial passou a ter maior publicidade, pois as decisões judiciais saíram dos redutos discretos dos fóruns para os holofotes da internet. Se antes um advogado precisava sair do escritório e ler páginas e mais páginas de autos processuais, hoje lhe basta uma busca refinada por palavras-chave, com filtros por tipo de decisão e tribunal, para que em poucos minutos compreenda com elevada probabilidade de acerto o entendimento jurisprudencial que lhe interessa. Como consequência, os litigantes passaram a contar com uma extensa base de dados de decisões judiciais para subsidiarem suas demandas, fenômeno que pode atingir as mais variadas modalidades processuais, inclusive a ação rescisória, tida pela doutrina como medida processual extrema.

Analisando neste conjunto a jurisprudência, que tem alta propagação e fácil acesso no meio digital (inclusive ao público leigo), há o perigo de, assim como tornamos banais (ou fluidos, como diz Bauman²) relacionamentos, tornarmos banal a jurisdição, tomando por comum o pronunciamento judicial, seja ele qual for — inclusive uma decisão proferida em ação rescisória, por exemplo.

Tal fato é observado na democratização do conhecimento sobre decisões judiciais aos que são alheios à área jurídica, pessoas que hoje têm condições de conversar sobre um

\footnotetext{
${ }^{2}$ Explica o autor sobre o emprego da metáfora: "Os fluidos, por assim dizer, não fixam o espaço nem prendem o tempo. Enquanto os sólidos têm dimensões espaciais claras, mas neutralizam o impacto e, portanto diminuem a significação do tempo (resistem efetivamente a seu fluxo ou o tornam irrelevante), os fluidos não se atêm muito a qualquer forma e estão constantemente prontos (e propensos) a mudá-la; assim, para eles, o que conta é o tempo, mais do que o espaço que lhes toca ocupar; espaço que, afinal, preenchem apenas 'por um momento'." Fonte: BAUMAN, Zygmunt. Modernidade líquida. Rio de Janeiro, Zahar, 2001, p. 8 .
} 
julgamento do Superior Tribunal de Justiça em uma roda de amigos e o compartilhar em suas redes sociais. A atuação da imprensa, nesse aspecto, soma-se à facilitação do acesso a essas informações na internet, haja vista sua cobertura constante sobre ações judiciais, inquéritos policiais etc., seja pela espetacularização que promove audiência, seja por sua importante função social de informar o cidadão.

Feito esse esclarecimento, deve-se levar em conta, nesse cenário, que o legislador vem prestigiando a jurisprudência enquanto forma de expressão do direito, terminologia empregada por Barreto Junior e Vigliar ao analisarem "As funções da jurisprudência na Sociedade da Informação" para designarem que:

O direito positivo e a jurisprudência devem ser vistos como manifestações do mesmo fenômeno jurídico, mesmo porque, nas lacunas e demais atividades integrativas, o labor jurisprudencial indicará qual a solução jurídica para o conflito, que deve ser solucionado, exista ou não uma lei específica à solução do conflito, diante da inafastabilidade do controle jurisdicional, que não permite o non liquet.

Percebe-se, nesse sentido, que se a jurisprudência e a lei são ambas formas de expressão do Direito, pode ser inadequado observar as decisões judiciais somente como resultado da sua aplicação ou, quando muito, sua fonte secundária. O ordenamento jurídico compreende a construção jurisprudencial das normas, cujo alcance e significado dependem justamente do que entendem as cortes a seu respeito. Os nominados autores ${ }^{4}$ apontam que a jurisprudência foi bastante fortalecida com a Emenda Constitucional n. 45, pela vinculação de decisões em Ação Direta de Inconstitucionalidade e em Ação Declaratória de Constitucionalidade, e o Código de Processo Civil de 2015, que abarca diferentes normas para uniformização de jurisprudência.

Nesse sentido, embora não haja equivalência entre uma decisão específica e um conjunto de decisões reiteradas, percebe-se que o papel estratégico da jurisprudência no ordenamento atual, que se afasta de uma interpretação literal e irrefletida de textos legais,

\footnotetext{
${ }^{3}$ BARRETO JUNIOR, Irineu Francisco; VIGLIAR, José Marcelo Menezes. As funções da jurisprudência na Sociedade da Informação. Revista da Faculdade de Direito da Universidade Federal de Minas Gerais, n. 73, p. 399, jul./dez. $2018 . \quad$ Disponível em: https://www.direito.ufmg.br/revista/index.php/revista/article/view/1953. $\quad$ DOI: $\quad$ 10.12818/P.03042340.2018V73P391. Acesso em 16 abr. 2020.

${ }^{4}$ BARRETO JUNIOR, Irineu Francisco; VIGLIAR, José Marcelo Menezes. As funções da jurisprudência na Sociedade da Informação. Revista da Faculdade de Direito da Universidade Federal de Minas Gerais, n. 73, p. 401, jul./dez. $2018 . \quad$ Disponível em: https://www.direito.ufmg.br/revista/index.php/revista/article/view/1953. DOI: $\quad$ 10.12818/P.0304-
} 2340.2018V73P391. Acesso em 16 abr. 2020. 
tem feito com que mesmo as decisões individuais influenciem demandas no Judiciário. Esse fenômeno segue uma lógica que atende a uma expectativa de segurança jurídica que proveja tratamento igualitário entre os jurisdicionados, de modo que ao terem demandas parecidas, obtenham decisões aproximadas.

Se a Sociedade da Informação aloca as manifestações jurisdicionais à luz do amplo conhecimento - porque isso possibilita significativo aumento de capital financeiro, informacional e de audiência —, sua força torna-se maior, passando a embasar mais facilmente a fundamentação de novas demandas que, ao mesmo tempo, tendem a tornar o comportamento dos tribunais mais dinâmico, pois ele diversas vezes se adapta a pressões externas (como a imprensa ou uma noção de opinião pública, por exemplo) ou internas (novas demandas, já previamente adaptadas aos óbices que se poderiam opor ao direito pleiteado), de forma que a fundamentação da nova decisão, ainda que produza o mesmo resultado, passa a integrar o conjunto de decisões à disposição do conhecimento público.

A jurisprudência assume, portanto, um papel norteador com o novo CPC, que busca através da uniformização das decisões construir uma sociedade dotada de segurança jurídica. É importante pensar que o processo possui caráter instrumental, de forma que a uniformização das decisões não se trata de mero conformismo ou facilidade de julgamento, mas de uma busca pela paz social, com tratamento igualitário e estabilidade nas relações.

Com essa função e esse efeito, a coisa julgada material não é instituto confinado ao direito processual. Ela tem acima de tudo o significado político-institucional de assegurar a firmeza das situações jurídicas, tanto que erigida em garantia constitucional. Uma vez consumada, reputa-se consolidada no presente e para o futuro a situação jurídico-material das partes, relativa ao objeto do julgamento e às razões que uma delas tivesse para sustentar ou pretender alguma outra situação. Toda possível dúvida está definitivamente dissipada, quanto ao modo como aqueles sujeitos se relacionam juridicamente na vida comum, ou quanto à pertinência de bens a um deles. As normas e técnicas do processo limitam-se a reger os modos como a coisa julgada se produz e os instrumentos pelos quais é protegida a estabilidade dessas relações - mas a função dessas normas e técnicas não vai além disso. ${ }^{5}$

$\mathrm{Na}$ Sociedade da Informação, sob os holofotes que a internet garante, a grande repercussão da jurisprudência alcança também o fator financeiro da informação.

\footnotetext{
${ }^{5}$ DINAMARCO, Candido Rangel. Relativizar a coisa julgada material. In Revista da Procuradoria Geral do Estado de São Paulo. Jan/dez 2001, n. 55-56, p. 35. Disponível em: http://www.pge.sp.gov.br/centrodeestudos/revistaspge/Revista\%20PGE\%2055-56.pdf. Acesso em 17 abr. 2020.
} 
Observando uma pessoa com uma demanda judicial talvez esta relação não fique clara, mas não se pode limitar o quadro; essa visão deve ser macro, pois os efeitos da internet o são. E essa abordagem suporta dois sentidos.

Primeiro, um olhar às grandes empresas da informação revela o citado aumento da audiência, mas também outro perigo, que enfrentamos diariamente ao acessar uma rede social ou baixar um novo aplicativo: dados pessoais de milhões de pessoas são disponibilizados na rede, tais como nome, endereço, documentos pessoais, a dispor, em pequena escala, de quem quiser procurar e, em larga escala, das grandes empresas detentoras de recurso tecnológico para extrair deles a informação e o valor de que necessitam. E, de igual forma, quanto à informação dos julgados, que demonstrando um ou outro entendimento pode se revelar relevante e valorosa economicamente a determinados setores, podendo ser, assim, um produto comercial das gigantes da informação.

Um segundo olhar revela um ponto essencial a este artigo. O jurisdicionado - seja um indivíduo com uma demanda ou uma grande empresa com contencioso de massa pode extrair conhecimento da informação disponibilizada nas manifestações jurisprudenciais. Determinado entendimento predominante pode ser decisivo para uma contratação milionária, tanto quanto para milhares de indivíduos desafortunados litigando massivamente contra empresas poderosas. Por outro lado, o entendimento minoritário pode parecer a tábua de salvação em outros casos. Não se deve ignorar a relevância e o valor que a jurisprudência possui. E essa questão é acentuada quando a ação rescisória é destacada.

\section{DA AÇÃO RESCISÓRIA}

Delineadas as considerações retro, cumpre analisar particularmente a ação rescisória. A análise do processo enquanto fonte de informações com valor mercadológico inevitavelmente transpassa a visão da sua instrumentalidade, que alude a ele como meio, forma, instrumento para alcançar determinado direito material. Isso significa que não é possível considerá-lo como fim em si mesmo; deve-se levar em conta seus efeitos na vida das pessoas, uma das razões, por exemplo, de se adotar o trânsito em julgado das decisões em ordenamentos jurídicos. Conforme Bedaque, "Se esse ato produz efeitos para fora do processo, sobre a relação material, a solução dada precisa estabilizar-se, sob pena de não 
conduzir à eliminação do litígio, frustrando-se por completo os escopos da função jurisdicional". 6

Assim, é de suma importância que o acesso ao Poder Judiciário, que garante o conhecimento e a resolução de conflitos, seja perene, se recrudescendo após transcorrido determinado período ou uma vez esgotados os recursos cabíveis, característica denominada trânsito em julgado. A ação rescisória, neste contexto, tem por fim instrumentalizar a possibilidade de relativização da coisa julgada, ou seja, afastar a imutabilidade da decisão em hipóteses extremamente restritas e taxativamente previstas.

A ação rescisória é ação autônoma de impugnação, medida excepcional prevista nos artigos 966 e seguintes do CPC e que tem por objetivo desconstituir decisão de mérito transitada em julgado que esteja viciada, de forma que a lide careça de nova apreciação, ou ainda, aquela que, embora não seja de mérito, impeça o ajuizamento de uma nova ação ou a admissibilidade de recurso. Apesar de não constituir espécie recursal, considerando que terá cabimento somente após o trânsito em julgado da decisão, a competência para conhecimento da ação rescisória é originária dos tribunais, sendo ela considerada um sucedâneo recursal. ${ }^{7}$

Essa medida processual pode ser considerada sucedâneo recursal porque tem por objetivo alegar e ver reconhecido vício presente na decisão proferida pelo juízo a quo, como intentam os recursos. Assemelha-se ainda aos recursos uma vez que estes podem ter suas razões legalmente vinculadas, como ocorre com a ação rescisória, sendo este o caso dos recursos Especial e Extraordinário, por exemplo. Entretanto, se difere da natureza recursal pelo momento processual em que será cabível, isto é, apenas após o trânsito em julgado, enquanto os recursos somente serão cabíveis antes dele.

Sua natureza jurídica, segundo Gonçalves ${ }^{8}$, sempre será desconstitutiva, uma vez que toda ação rescisória objetivará rescindir total ou parcialmente decisão transitada em julgado, isto é, terá o juízo rescidente. Poderá ter natureza condenatória, constitutiva ou

\footnotetext{
${ }^{6}$ BEDAQUE, José Roberto dos Santos. Direito e Processo: influência do direito material sobre o processo. 6 ed. São Paulo, Malheiros, 2011, p.134-135.

${ }^{7}$ NEVES, Daniel Amorim Assumpção, Manual De Direito Processual Civil - Volume Único. 8 ed. Salvador: JusPodivm, 2016, p. 1338.

${ }^{8}$ GONÇALVES, Marcus Vinicius Rios. Direito Processual Civil Esquematizado. 8 ed. São Paulo: Saraiva, 2017, p. 710.
} 
declaratória, no caso de exercido também juízo rescindendo, isto é, se prolatada nova decisão para o caso.

Por se tratar de medida excepcional, a ação rescisória tem hipóteses de cabimento taxativamente previstas nos incisos do art. 966 do CPC, havendo também previsão para seu excepcional cabimento nos artigos 525, $\S 15$, e 535, $\S 8^{\circ}$, ambos do CPC, para os casos em que a de decisão transitada em julgado e ora exequenda seja baseada em lei tida por inconstitucional pelo STF, e no art. 658 do CPC, aplicável à partilha. Além disso, só terá cabimento a medida nos prazos estabelecidos em lei e através de propositura por um dos legitimados. Por fim, destaque-se que este instrumento processual não terá cabimento nos procedimentos dos juizados especiais, nos termos do art. 59 da Lei 9.099/1995, ou contra decisões em sede de ADIN ou ADPF, nos termos do art. 26 da Lei 9.868/1999.

Além das determinações do art. 319 para a petição inicial, o art. 968 e seus incisos, ambos do CPC, indicam os pressupostos específicos para a ação rescisória. O primeiro deles é a cumulação, se o caso, dos pedidos de rescisão da decisão impugnada e de novo julgamento da lide. Ou seja, o pedido para afastar o trânsito em julgado da decisão impugnada, de forma a possibilitar o conhecimento da matéria e oportunizar o pedido de novo julgamento.

O segundo pressuposto de admissibilidade da ação é o depósito prévio do montante equivalente a $5 \%$ sobre o valor da causa, que será convertido em multa em benefício da parte adversa nos casos de inadmissão ou improcedência da ação por unanimidade de votos. Historicamente, este requisito encontra correspondência no direito medieval português, que, como requisito do pedido de desconstituição da coisa julgada, exigia uma multa fixada em 5\% sobre o valor da causa na hipótese de improcedência do pedido, garantindo a seriedade do pedido. ${ }^{9}$

Atualmente no Brasil, o requisito do depósito, à exceção dos casos em que haja concessão do benefício da justiça gratuita ou cuja demanda seja proposta por entes da Federação, será obrigatório e revertido ao demandado nas hipóteses de inadmissão ou improcedência do pedido por unanimidade. Consideradas essas poucas exceções

\footnotetext{
${ }^{9}$ MITIDIERO, Daniel. Ação Rescisória no Direito Comparado: da Comparação Vertical à Comparação Horizontal. Revista de Processo Comparado, v. 5, 2017. Disponível em: http://revistadeprocessocomparado.com.br/wp-content/uploads/2017/10/Daniel-Mitidiero-v.-5.pdf. Acesso em 27 fev. 2019, p. 09.
} 
destacadas ${ }^{10}$, a petição inicial que não cumprir o requisito do depósito prévio será indeferida, nos termos do $\S 3^{\circ}$ do artigo 968 do CPC.

Conforme acima exposto, o depósito poderá ser convertido em multa em benefício da parte adversa, indicando uma possível penalidade àquele que utilizar indevidamente a medida, como forma de proteger sua excepcionalidade, a qual garante a segurança jurídica proposta pelo trânsito em julgado. ${ }^{11}$

Percebe-se, portanto, que se trata de uma ação com espectro bastante restrito, de modo que a rescisão da coisa julgada, para o legislador, não é situação corriqueira ou que mereça ser facilitada, mesmo em detrimento da realidade fática sobre a qual versam os autos - trata-se sempre de uma escolha, em prol da segurança jurídica. Não é isso, afinal, o que o ocorre com o instituto da prescrição? Transcorrido prazo legal, o interessado perde o direito processual de pleitear determinado direito. Contudo, deve-se observar que o contexto da Sociedade da Informação pode permitir situações que ponham essa restrição à prova, exigindo dos tribunais uma reação sólida e estável.

\section{A AÇÃO RESCISÓRIA NA SOCIEDADE DA INFORMAÇÃO}

Considerando o caráter excepcional da ação rescisória como meio para resguardar a necessária segurança jurídica assegurada através do trânsito em julgado das decisões, bem como o novo cenário de visibilidade das decisões ocasionada pela internet e pelas mídias de forma geral, e, ainda, o contexto socioeconômico da Sociedade da Informação, pode-se relacionar cada uma dessas questões para observar uma situação que pode ser enfrentada pelo sistema processual em relação à rescindibilidade das decisões judiciais.

As hipóteses de rescindibilidade das decisões com trânsito em julgado constituemse em rol propositalmente restrito, já que a relativização da coisa julgada deve ser sempre a exceção. Esse entendimento é o que baliza, por exemplo, o depósito prévio de $5 \%$ do valor da causa (art. 968, II, do CPC) ou de $20 \%$ se ação visar a rescindir decisão da Justiça do Trabalho (art. 836 da CLT). O depósito prévio evita as chamadas demandas aventureiras e

\footnotetext{
${ }^{10}$ Segundo a Súmula 175 do STJ, também "Descabe o depósito prévio nas ações rescisórias propostas pelo INSS".

${ }^{11}$ NEVES, Daniel Amorim Assumpção, Manual De Direito Processual Civil - Volume Único. 8 ed. Salvador: JusPodivm, 2016, p. 1360.
} 
a banalização da coisa julgada, embora suscite discussões acaloradas acerca da sua constitucionalidade, recentemente reafirmada pelo Supremo Tribunal Federal. ${ }^{12}$

$\mathrm{O}$ perigo cresce quanto à rescisão da coisa julgada, que deve ser sempre excepcional no ordenamento jurídico que busca resguardar a segurança jurídica. Ora, ao legislador teria sido impossível prever essa realidade, mas ainda assim encontram-se requisitos específicos restringindo a propositura da ação rescisória, tais como suas hipóteses de cabimento e o depósito prévio, que tendem a impedir ou ao menos diminuir a aventura jurídica e, por consequência, evitar a banalização da possibilidade de afastar a coisa julgada - daí porque se considera a ação rescisória uma medida processual extrema ou um remédio extremo, como dizem Marinoni, Arenhart e Mitidiero. ${ }^{13}$

Destaque-se que essa banalização implicaria insegurança jurídica e consequentes dúvidas quanto aos negócios jurídicos desde sua fase pré-contratual, por exemplo. E o olhar para a informação como valor, recurso, processo e produto nos mostra o quanto ela (especialmente enquanto informação sobre a estabilidade jurídica no País) é valiosa.

É importante notar que este artigo não aborda a relativização da coisa julgada de fato, mas o enfraquecimento prático dos seus efeitos, isto é, que, enquanto objeto de discussão de ação rescisória, a coisa julgada tenha sua importância minorada em detrimento de um olhar irrefletido a uma decisão anteriormente proferida no julgamento de uma demanda que tenha similitude fática com aquela cuja decisão se pretende rescindir. Cuida-se de esclarecer esse tópico por haver tímidas iniciativas a defenderem uma relativização da coisa julgada de fato, a partir de uma "possibilidade" de sua revisão sem ação rescisória:

Em razão de certos casos, há quem sustente a possibilidade de se desconsiderar a sentença transitada em julgado - produtora de coisa julgada - sem a necessidade da propositura de ação rescisória. Um dos exemplos que tem sido usado para dar fundamento a essa tese é o da ação de investigação de paternidade, cuja sentença transitada em julgado declarou que o autor não é filho do réu (ou o inverso), vindo depois um exame de DNA a demonstrar o contrário. Diante disso, e para tornar possível a rediscussão do que foi afirmado pela sentença transitada em julgado, argumenta-se que a indiscutibilidade da coisa julgada não pode

12 STF. ADI 3.995 DF. Rel. Min. Roberto Barroso. DJE 1 mar. 2019. Disponível em: https://portal.stf.jus.br/processos/downloadPeca.asp?id=15339621153\&ext=.pdf. Acesso em 29 abr. 2020.

${ }^{13}$ MARINONI, Luiz Guilherme; ARENHART, Sérgio Cruz; MITIDIERO, Daniel. O novo processo civil. 2 ed. rev. atual. e ampl. São Paulo: Revista dos Tribunais, 2016, p. 576. 
prevalecer sobre a realidade e que assim deve ser possível rever a conclusão formada. ${ }^{14}$

Afastar a ação rescisória para rescindir decisão com trânsito em julgado seria, possivelmente, um devaneio. Não porque o processo está acima do direito material — nem poderia estar, em razão da sua instrumentalidade - , mas porque isso lhe tiraria sua função de prover segurança jurídica em um Estado de Direito. No próprio exemplo mencionado pelos autores supracitados, poder-se-ia rescindir a decisão pela hipótese do art. 966, VII, do CPC, por haver uma prova nova da qual o interessado não poderia ter feito uso à época da prolação da decisão cujo dispositivo se pretenderia alterar. Nesse sentido, Marinoni, Arenhart e Mitidiero ${ }^{15}$ destacam, quanto à coisa julgada:

A coisa julgada não se confunde, nem pode ser identificada, com uma imaginada fixação da verdade para o caso concreto. A rigor, a coisa julgada é apenas a escolha estatal por colocar um fim no procedimento, ainda que outra resposta pudesse ser melhor ou que outra solução, no futuro, venha a mostrar-se mais recomendada.

É por esse motivo, porque a coisa julgada não consiste numa projeção de uma verdade ficta aos autos, que o Estado reconhece sua falibilidade e prevê um rol possível, embora restrito, de hipóteses para a ação rescisória. Para isso, deve-se levar em conta a segurança jurídica e sua importância na vida das pessoas. Como este artigo observou, o processo possui caráter instrumental, ou seja, não tem sua função nem sua finalidade em si mesmo, mas, como instrumento, atua para alcançar a vida das pessoas, a fim de colocar fim aos conflitos da sociedade e pacificá-la.

Ao tratar da ação rescisória, Dinamarco ${ }^{16}$ destaca a segurança nas relações jurídicas, apontando-a como "poderoso fator de paz na sociedade e felicidade pessoal de cada um”, já que a jurisdição será, também para referido autor, o fim das incertezas que mantinham as partes em "desconfortável estado de angústia”. E ainda esclarece que o fenômeno da coisa julgada:

\footnotetext{
${ }^{14}$ MARINONI, Luiz Guilherme; ARENHART, Sérgio Cruz; MITIDIERO, Daniel. O novo processo civil. 2 ed. rev. atual. e ampl. São Paulo: Revista dos Tribunais, 2016, p.596.

${ }^{15}$ MARINONI, Luiz Guilherme; ARENHART, Sérgio Cruz; MITIDIERO, Daniel. O novo processo civil. 2 ed. rev. atual. e ampl. São Paulo: Revista dos Tribunais, 2016, p. 588.

${ }^{16}$ DINAMARCO, Candido Rangel. Relativizar a coisa julgada material. In Revista da Procuradoria Geral do Estado de São Paulo. Jan/dez 2001, n. 55-56, p. 34. Disponível em: http://www.pge.sp.gov.br/centrodeestudos/revistaspge/Revista\%20PGE\%2055-56.pdf. Acesso em 17 abr. 2020.
} 
Não se trata de imunizar a sentença como ato do processo, mas os efeitos que ela projeta para fora deste e atingem as pessoas em suas relações - e daí a grande relevância social do instituto da coisa julgada material, que a Constituição assegura (art. $5^{\circ}$, inc. XXXVI) e a lei processual disciplina (arts. 467 ss.). ${ }^{17}$

A partir dessa concepção, compreende-se melhor a importância da segurança jurídica. Ela tem por finalidade impedir esse estado de angústia ao qual o autor se refere, buscando a paz social e felicidade pessoal dos jurisdicionados. Muito além de imunizar uma decisão, ela alcança os efeitos que terá na vida das pessoas. Tal é a importância da coisa julgada.

Assim, a análise da rescindibilidade da coisa julgada deve, como em uma superfície porosa, ter todo esse contexto transpassado, para se compreender a razão pela qual essa medida, instrumentalizada na ação rescisória, possui caráter excepcional. Não se deve, ao nível legal, oportunizar uma fácil mitigação desses direitos de paz social e felicidade pessoal. Ao contrário, deve-se evitar ao máximo essa situação.

Como foi salientado, com a Emenda Constitucional 45/2004 iniciou-se uma nova fase no ordenamento jurídico brasileiro, que encontrou seu ápice no novo Código de Processo Civil, em que é concedida maior força aos pronunciamentos judiciais. No mundo contemporâneo prevalecem, a depender da cultura de cada país, as bases jurídicas no processo legislativo (civil law) ou no processo jurisdicional (common law). ${ }^{18}$ Entretanto, neste momento podemos dizer que o ordenamento jurídico brasileiro se transmudou, passando a conceber ambos os processos como fontes de direito.

Isso se demonstra nos diversos artigos do CPC cujas previsões determinam que sejam observados os precedentes e que a jurisprudência seja uniforme, culminando até na possível nulidade de uma decisão que não se manifeste sobre precedente arguido pela parte, deixando de aplicá-lo sem demonstrar sua superação ou a distinção ao caso, hipótese em que é considerada não fundamentada. Essa nova força concedida à jurisprudência, quando aplicada especificamente ao contexto da rescindibilidade da coisa julgada,

\footnotetext{
${ }^{17}$ DINAMARCO, Candido Rangel. Relativizar a coisa julgada material. In Revista da Procuradoria Geral do Estado de São Paulo. Jan/dez 2001, n. 55-56, p. 36. Disponível em: http://www.pge.sp.gov.br/centrodeestudos/revistaspge/Revista\%20PGE\%2055-56.pdf. Acesso em 17 abr. 2020.

${ }^{18}$ REALE, Miguel. Lições preliminares do direito. São Paulo, Saraiva, 2002, p. 154.
} 
encaminha - em um contexto jurídico total, e não apenas jurisdicional, pois não cabe apenas ao juízo resguardar esses preceitos, mas a todos — à maior cautela.

Com o papel da jurisprudência hipertrofiado em relação ao paradigma de 1973, ainda que as hipóteses de rescindibilidade de decisões com trânsito em julgado permaneçam restritas e as decisões em ações rescisórias produzam efeitos apenas inter partes, deve-se observar esse tipo de demanda com especial atenção numa perspectiva jurídico-sociológica, que considere o Direito num cenário mais amplo, para além de um dogmatismo imediato. Independentemente do ideal normativo, do mundo do dever-ser do ordenamento, já há quem proponha a relativização da coisa julgada independentemente de ação rescisória. E ainda que se considerem as inconsistências teóricas por trás disso, há dois fatores essenciais a um olhar crítico sobre essa questão.

O primeiro tem a ver com a disseminação de informações sobre decisões judiciais e seu possível aproveitamento à fundamentação em ações ajuizadas em efeito manada, de modo que a partir de determinada decisão paradigma, diversos processos são inaugurados com o mesmo pedido. A Sociedade da Informação favorece o rápido e eficiente conhecimento do público acerca de todas as decisões judiciais. E se elas constituem a jurisprudência, importante forma de expressão do Direito, certamente irradiam efeitos indiretos a sujeitos estranhos aos processos nos quais são proferidas, ainda que não produzam, diretamente, efeitos extra partes.

É importante esclarecer quais seriam esses efeitos indiretos para os sujeitos estranhos ao processo. É cediço que, atentando ao princípio do contraditório, amplamente garantido no novo CPC, não seria possível impor a decisão a um terceiro alheio à lide, pessoa que não participou do convencimento do juízo, que é justamente o que legitima a atividade jurisdicional. Contudo, não se pode negar que existe um efeito indireto - se não gerado, acentuado pelo sistema de precedentes. Esse efeito é a vinculação das decisões judiciais, que não podem revelar incontáveis entendimentos esparsos, mas devem manter uniforme a jurisprudência e assegurar a autoridade das decisões dos tribunais, resultando no que esta pesquisa chama de efeito indireto da decisão, que garante ao terceiro alheio à lide isonomia e estabilidade nos pronunciamentos jurisdicionais. 
O segundo fator consiste numa possível subsunção da jurisdição estatal àquilo que Bauman observou no contexto que chamou de modernidade líquida ${ }^{19}$, o descontentamento recorrente que liquefaz algo que até a modernidade era sólido: a jurisdição, bem como o instituto da coisa julgada, que começa a perder sua força, já havendo inclusive quem proponha sua relativização independentemente de ação rescisória.

O perigo está, assim, na fluidez que aflige os tempos pós-modernos. Bauman ${ }^{20}$, explicando uma origem do ideal que liquefaz os sólidos pré-modernos, então buscado não para que vivêssemos na vida líquida, incerta, mas para que pudéssemos alcançar novos sólidos, que fossem mais confiáveis, sustenta que um dos primeiros sólidos a derreter foram os direitos costumeiros. Ainda que hoje, conforme referido autor ${ }^{21}$, a busca por esses novos sólidos mais confiáveis tenha sido abandonada, de forma que vivemos de fato na modernidade líquida, isso revela a importância das decisões judiciais. Não por outra razão foram naquele tempo os primeiros alvos da liquefação, para possibilitar novas posições e propiciar uma transformação social.

O ideal original, que traria novos sólidos, atenderia de uma forma mais adequada à segurança jurídica, já que concederia estabilidade e certeza quanto aos entendimentos jurisdicionais, ainda que estes fossem renovados. Entretanto, este ideal foi abandonado. A sociedade está habituada à modernidade líquida, à comparação universal que se opõe aos grupos de referência, ao choque e à contradição dos comandos, em detrimento da certeza e estabilidade de outrora. $^{22}$ Os institutos processuais destacados, que buscam essa estabilidade e segurança na sociedade, se contrapõem, portanto, a esta realidade, provendo certeza do comando e referências adequadas. Cabe destacar, contudo, que "Manter os fluidos em uma forma requer muita atenção, vigilância constante e esforço perpétuo $[\ldots] " \cdot 23$

\footnotetext{
19 Bauman utiliza o termo "líquido" para qualificar a modernidade. A modernidade é líquida e, por consequência, são líquidos o medo, a vigilância, o amor, entre outros temas. Este contexto consiste em uma modernidade individualizada e privatizada. Os padrões que antes eram certos, sólidos, são agora liquefeitos, têm sua certeza retirada, enquanto é trazido um olhar individualizado. A forma que o objeto em análise possui já não é mais certa, mas assume o formato que lhe seja proposto, tornando-se maleável. Essa fluidez, ainda que permita colocar uma forma ao objeto, dificulta que a forma se mantenha.

${ }^{20}$ BAUMAN, Zygmunt. Modernidade líquida. Rio de Janeiro, Zahar, 2001, p. 10.

${ }^{21}$ BAUMAN, Zygmunt. Modernidade líquida. Rio de Janeiro, Zahar, 2001, p. 12.

${ }^{22}$ BAUMAN, Zygmunt. Modernidade líquida. Rio de Janeiro, Zahar, 2001, p. 15.

${ }^{23}$ BAUMAN, Zygmunt. Modernidade líquida. Rio de Janeiro, Zahar, 2001, p. 15.
} 
Esse processo de relativização da coisa julgada não deveria nos surpreender em demasia: se o que era sólido hoje é líquido e se esvai entre os nossos dedos, se nossos trabalhos, medos e amores têm prazo de validade e são trocados numa busca por satisfação (ou insatisfação) constante, por que haveríamos de permanecer satisfeitos com as decisões judiciais? O Direito, por outro lado, tem a constância como característica precípua, pelo que haverá, provavelmente, um movimento de resistência e cada vez maior afunilamento de alteração de decisões, especialmente daquelas com trânsito em julgado.

A Sociedade da Informação, que hoje tem suas atividades ancoradas nas novas tecnologias da informação, proporciona o rápido e integral conhecimento das decisões judiciais, o que tem se revelado uma facilitação à aplicação deste sistema de precedentes estabelecido pelo CPC, porque o jurisdicionado os conhece e cobra do Poder Judiciário a uniformização da jurisprudência. Isso somado a essa liquefação própria da pósmodernidade, que tem como alvo também os precedentes, como seu histórico demonstra, encaminha a uma possível massificação das ações rescisórias.

O olhar individualizado para a jurisdição, a constante busca por colocá-la nas formas ditadas por cada parte, resulta num possível prisma ordinário à ação rescisória. $\mathrm{O}$ esforço legislativo para garantir sua excepcionalidade está em ameaça pelo conjunto de características da Sociedade da Informação somadas às da Modernidade Líquida. Daí a importância de o uso da ação rescisória não perder sua excepcionalidade e se manter condição sine qua non à rescisão de julgados.

Deve-se resguardar a solidez das decisões, do trânsito em julgado, e esse resguardo deve ser revelado no momento de propositura da ação rescisória, tanto quanto no momento de julgamento da ação, já que cada um dos participantes do processo terá o compromisso de resguardar a excepcionalidade da rescindibilidade das decisões. Pois de outra forma, com a liquefação da jurisdição, isto é, com esse olhar individualista, incerto, sem referência, o sistema de precedentes sequer poderá adequadamente se estabelecer, a coisa julgada gradativamente perderá sua força e importância social e a ação rescisória, sua excepcionalidade.

\section{CONSIDERAÇÕES FINAIS}


Este artigo pretendeu, por meio de pesquisa jurídico-sociológica, observar a ação rescisória no contexto da Sociedade da Informação, aproveitando reflexões acerca da Modernidade Líquida, com o fim de verificar as formas pelas quais as transformações sociais vêm influenciando a aplicação da norma processual. Há um aparente efeito indireto das decisões aos sujeitos estranhos às lides em que são prolatadas, devido à sua superpublicidade na internet. Ao mesmo tempo em que parece haver processo de relativização da coisa julgada em curso, o que pode, dialeticamente, ser um elemento que demande especial atenção ao prisma estrito da ação rescisória a fim de resguardar a segurança jurídica.

A ação rescisória tem um rol de cabimento propositalmente estrito, haja vista que a rescisão da coisa julgada deve ser sempre uma possibilidade excepcional prevista pelo ordenamento. Isso serve, de um lado, a permitir que o jurisdicionado não seja vitimizado por eventual vício da decisão que a destoe da realidade fática ou da legalidade e, de outro canto, a evitar demandas aventureiras e, em última instância, a banalização da coisa julgada.

$\mathrm{Na}$ Sociedade da Informação, não há apenas as decisões simplesmente disponibilizadas na internet, ampliando as possibilidades que tínhamos indo ao fórum para nos informarmos. Mais que isso, há diversos sistemas de pesquisa por palavras-chave e diversos filtros — que não se resumem àqueles disponibilizados pelos tribunais —, bem como diversos agentes na rede que republicam intimações judiciais, atendendo à lógica econômica da informação na sociedade em rede.

Esse fenômeno permite que os litigantes se informem em poucos minutos acerca de decisões recentes das cortes às quais pleiteiam seus direitos, de modo que não se embasam simplesmente em decisões vinculantes ou nas disposições técnicas de uniformização de jurisprudência; todo e qualquer acórdão pode se tornar um argumento na fundamentação de quem pretenda convencer o Juízo - este que está inserto na expectativa do legislador e da sociedade de manter a coesão dos pronunciamentos judiciais. Assim, se o novo sistema processual aproxima o ordenamento brasileiro de preceitos típicos da common law, ainda que uma decisão produza efeitos somente inter partes, ela pode irradiar efeitos indiretos a outras demandas, como recurso argumentativo - não meramente retórico, mas que implica uma expectativa de uniformidade jurisprudencial. 
A par dessa situação que já é desafiadora por si só, a fluidez das relações na Modernidade Líquida vem liquefazendo os sólidos do século XX - a começar pelo próprio Direito, no contexto observado por Bauman ${ }^{24}$-, de modo que as relações que antes eram revestidas de solidez e continuidade passam a se volatilizar em meio a uma busca pelo contentamento (ou descontentamento) constante.

Nesse sentido, a sociedade permanece em um processo de busca por uma satisfação impossível - em relação ao processo civil, sabe-se que a pacificação social e a felicidade pessoal dos litigantes são ideais que jamais serão atingidos de fato, como se uma sentença encerrasse todas as agruras de um conflito levado ao Judiciário. É a inafastabilidade do Estado para solucionar conflitos o que inspira a necessidade de certo grau de imutabilidade das decisões com trânsito em julgado o que visa a atender à segurança jurídica, imprescindível em um Estado de Direito.

Há uma tensão entre duas situações perseguidas pela sociedade: de um lado, a solidez que o legislador espera da coisa julgada. De outro, a fluidez com a qual a sociedade vem se habituando desde o advento da pós-modernidade. Este fenômeno talvez dê uma pista acerca de fatores que têm o potencial de relativizar a coisa julgada.

O primeiro é a banalização da ação rescisória (cuja excepcionalidade precisa ser incansavelmente ressaltada pela doutrina) que pretende convertê-la em mais um recurso e no contexto socioeconômico atual pode ter seu ajuizamento consideravelmente facilitado pelo conhecimento instantâneo e massivo sobre outras ações.

O segundo consiste nas abordagens recentes que chegam a desconsiderar a ação rescisória como condição para rescindir decisão com trânsito em julgado, em detrimento, pelo exemplo estudado neste artigo, da realidade fática - o que denota $o$ descontentamento individual como elemento que equipara a sentença a um produto comprado no supermercado: se não me agrada, obtenho outro.

Tendo em vista a segurança jurídica almejada pelo Direito, uma das principais expectativas do jurisdicionado, é preocupante que, paradoxalmente, a maior valorização da atividade jurisdicional enquanto sua expressão se desvirtue e se torne um elemento catalisador de mais ações em efeito manada - hoje tendência de inúmeros temas debatidos no Judiciário, por conta da disseminação instantânea (e por vezes imbuída de

\footnotetext{
${ }^{24}$ BAUMAN, Zygmunt. Modernidade líquida. Rio de Janeiro, Zahar, 2001, p. 10.
} 
interesse econômico de agentes na internet) —, enfraquecendo a estabilidade da coisa julgada.

Daí porque se deve ter especial atenção à necessidade de solidez da coisa julgada, talvez com maior intensidade do que tivemos ao longo da modernidade. A liquefação dos sólidos do século XX é uma transformação social espontânea que atinge diferentes segmentos de formas diversas e, portanto, não parece ser um problema em si. Contudo, ela exige atenção constante para manter esses elementos — que se solidificam cada vez menos — da forma almejada pela sociedade. Um líquido precisa de um recipiente seguro para se manter estável.

\section{REFERÊNCIAS:}

BARRETO JUNIOR, Irineu Francisco; VIGLIAR, José Marcelo Menezes. As funções da jurisprudência na Sociedade da Informação. Revista da Faculdade de Direito da Universidade Federal de Minas Gerais, n. 73, pp. 391-417, jul./dez. 2018. Disponível em: https://www.direito.ufmg.br/revista/index.php/revista/article/view/1953. DOI: 10.12818/P.0304-2340.2018V73P391. Acesso em 16 abr. 2020.

BAUMAN, Zygmunt. Modernidade líquida. Rio de Janeiro, Zahar, 2001.

BEDAQUE, José Roberto dos Santos. Direito e processo: influência do direito material sobre o processo. São Paulo, Malheiros, 2011.

BRASIL, Constituição da República Federativa do Brasil de 1988.

BRASIL, Lei $n^{\circ} 13.105$, de 16 de março de 2015.

DIDIER, Fredie. Curso de Direito Processual Civil: O Processo Civil nos Tribunais, Recursos, Ações de Competência Originária de Tribunal e Querela Nullitatis, Incidentes de Competência Originária de Tribunal. Salvador: JusPodivm, 2016.

DINAMARCO, Candido Rangel. Relativizar a coisa julgada material. In Revista da Procuradoria Geral do Estado de São Paulo. Jan/dez 2001, n. 55-56, p. 31-78. Disponível em: http://www.pge.sp.gov.br/centrodeestudos/revistaspge/Revista\%20PGE\%205556.pdf. Acesso em 17 abr. 2020. 
GONÇALVES, Marcus Vinicius Rios. Direito Processual Civil Esquematizado. 8 ed. São Paulo: Saraiva, 2017.

MARINONI, Luiz Guilherme; ARENHART, Sérgio Cruz; MITIDIERO, Daniel. O novo processo civil. 2 ed. rev. atual. e ampl. São Paulo: Revista dos Tribunais, 2016.

MARINONI, Luiz Guilherme. Técnica processual e tutela dos direitos. São Paulo: Thomson Reuters Brasil, 2019.

MITIDIERO, Daniel. Ação Rescisória no Direito Comparado: da Comparação Vertical à Comparação Horizontal. Revista de Processo Comparado, v. 5, 2017. Disponível em: http://revistadeprocessocomparado.com.br/wpcontent/uploads/2017/10/Daniel-Mitidiero-v.-5.pdf. Acesso em 27 fev. 2019.

NEVES, Daniel Amorim Assumpção, Manual De Direito Processual Civil - Volume Único. 8 ed. Salvador: JusPodivm, 2016.

REALE, Miguel. Lições preliminares do direito. São Paulo, Saraiva, 2002. 